\title{
PENGARUH MANUAL HANDLING TERHADAP KELUHAN MUSCULOSKELETAL DISORDERS PADA PEKERJA ANGKAT ANGKUT DI CV. AMANAH
}

\author{
Nikmah Khairani ${ }^{1}$, Tri Niswati Utami ${ }^{2}$ \\ Fakultas Kesehatan Masyarakat Universitas Islam Negeri Sumatera Utara ${ }^{1,2}$ \\ nikmahkhairani99@gmail.com¹ ${ }^{1}$,riniswatiutami@uinsu.ac.id ${ }^{2}$
}

\begin{abstract}
Handling materials manually by relying on human labor is very possible for the emergence of occupational safety and health problems, considering that human capacity in doing a job is very limited. When compared to using manual handling tools, it has advantages because of the flexibility of movement that can be done for light loads. But besides that, manual handling activities can also cause occupational diseases and are at high risk. Manual handling activities can cause low back pain caused by lifting weights, pushing and pulling loads, throwing, carrying, pulling and holding loads. The purpose of this study was to determine the effect of manual handling on complaints of musculoskeletal disorders in lifting workers at CV. Trust. This research uses quantitative research, analytical survey method with cross sectional research approach. The sample in this study were 31 respondents, namely lifting workers at CV. Trust. The sampling technique in this study is total sampling. The results of this study using the chi-square test analysis obtained that the independent and dependent variables have an influence $(\rho=0.000)$ where the value of value is smaller than $(\alpha=$ 0.05). Based on these results, it can be concluded that there is an effect of manual handling on complaints of musculoskeletal disorders in lifting workers at CV. Trust. As for suggestions for business owners to provide ergonomic work tools for workers when lifting heavy loads and for researchers to re-design work tools.
\end{abstract}

Keywords $\quad$ : Manual Handling,Musculoskeletal Disorders Complaint, Pick Up

\begin{abstract}
ABSTRAK
Penangan material secara manual dengan mengandalkan tenaga manusia sangat memungkinkan munculnya permasalahan keselamatan dan kesehatan kerja, mengingat kapasitas manusia dalam melakukan suatu pekerjaan sangat terbatas. Bila dibandingkan dengan menggunakan alat bantu pemanfaatan manual handling memiliki kelebihan karena fleksibilitas gerakan yang dapat dilakukan untuk beban-beban ringan. Namun disamping itu aktivitas manual handling juga dapat menyebabkan timbulnya penyakit akibat kerja dan berisiko tinggi. Aktivitas manual handling dapat menyebabkan nyeri pinggang yang diakibatkan oleh aktivitas mengangkat beban, mendorong dan menarik beban, melempar, membawa, menarik dan menahan beban. Tujuan dari penelitian ini adalah untuk mengetahui pengaruh manual handling terhadap keluhan musculoskeletal disorders pada pekerja angkat angkut di CV. Amanah. Penelitian ini menggunakan jenis penelitian kuantitatif, metode survey analitik dengan pendekatan penelitian cross sectional. Sampel dalam penelitian ini sejumlah 31 orang responden yaitu pekerja angkat angkut di CV. Amanah. Teknik sampling pada penelitian ini adalah total sampling. Hasil penelitian ini menggunakan analisis uji chi-square diperoleh variabel bebas dan terikat memeiliki pengaruh $(\rho=0,000)$ dimana nilai $\rho$ value lebih kecil dari $\alpha(\alpha=0,05)$. Berdasarkan hasil tersebut dapat disimpulan bahwa ada pengaruh manual handling terhadap keluhan musculoskeletal disorders pada pekerja angkat angkut di CV. Amanah. Adapun saran kepada pemilik usaha agar menyediakan alat kerja yang ergonomi untuk pekerja pada saat mengangkat beban berat dan untuk peneliti melakukan re design alat kerja.
\end{abstract}

Kata kunci : Angkat Angkut, Keluhan Musculoskeletal Diosrders, Manual Handling 


\section{PENDAHULUAN}

Penanganan material secara manual dengan mengandalkan tenaga manusia sangat memungkinkan munculnya permasalahan keselamatan dan kesehatan kerja, mengingat kapasitas manusia dalam melakukan suatu pekerjaan sangat terbatas. Maka dari itu, perlunya upaya untuk meningkatkan keselamatan dan kesehatan kerja (K3) untuk menekan angka kecelakaan kerja maupun penyakit akibat kerja dan juga untuk meningkatkan produktivitas kerja. Sebagaimana yang termasuk dalam Undang-Undang No. 13 Tahun 2003 tentang Ketenagakerjaan pasal 86 ayat 1 menyebutkan bahwa setiap pekerja mempunyai hak untuk memperoleh perlindungan atas keselamatan dan kesehatan kerja. Aspek kesehatan kerja yang mungkin muncul akibat penanganan material secara manual dan perlu untuk diperhatikan salah satunya adalah penyakit akibat kerja (Azis, 2018)

Pemanfaatan tenaga manusia masih sangat dibutuhkan dalam penanganan material secara manual (manual handling). Bila dibandingkan dengan menggunakan alat bantu pemanfaatan manual handling memiliki kelebihan karena fleksibilitas gerakan yang dapat dilakukan untuk beban-beban ringan. Namun disamping itu aktivitas manual handling juga dapat menyebabkan timbulnya penyakit akibat kerja dan berisiko tinggi. Aktivitas manual handling dapat menyebabkan nyeri pinggang yang diakibatkan oleh aktivitas mengangkat beban sebanyak 50\%, mendorong dan menarik beban sebanyak 9\%, melempar, membawa, menarik dan menahan beban sebanyak 6\% (Noe, 2020).

Word Health Organization (WHO) menyebutkan kontribsi dari berbagai faktor risiko dapat memperberat gangguan musculoskeletal disorders. Faktor risiko tersebut antara lain faktor individu, faktor pekerjaan atau biomekanik dan faktor psikososial (Cho K, Cho HY, 2016).

International Labour Organization (ILO) pada Tahun 2018 menyebutkan bahwa terdapat 1 orang pekerja setiap 15 detik yang meninggal dunia karena kecelakaan kerja dan mengalami sakit akibat kerja sebanya 160 pekerja. Sebelumnya pada tahun (2012) terdapat 2 juta kasus kematian yang terjadi setiap tahunnya yang diakibatkan oleh penyakit akibat kerja dan kecelakaan kerja (Kemenkes, 2014). International Labour Organization (ILO) perkiraan yang terbaru terdapat 2,78 Juta pekerja yang meninggal setiap tahun disebabkan penyakit akibat kerja, namun lebih dari $380.000(13,7 \%)$ yang disebabkan oleh kecelakaan kerja (ILO, 2018).

Menurut WHO secara global sekitar 20\%-33\% orang hidup dengan keluhan musculoskeletal (WHO, 2019). Pada tahun 2019, Labour Force Survey (LFS) melaporkan bahwa sebanyak 498.000 pekerja Britania Raya mengalami keluhan musculoskeletal. Keluhan ini sering dialami pada ekstremitas dan leher (41\%), serta ekstremitas bawah (19\%) (HSE, 2019). (U.S Beureau of Labour Statistics (BLS) dari data yang dilihat pada tahun 2015 menjelaskan bahwa kejadian musculoskeletal disorders yang disebabkan dari pekerjaan yang dipaksakan saat proses angkat berjumlah sekitar 256.910 kasus atau sekitar $31 \%$ dari jumlah kejadian kecelakaan kerja dan penyakit akibat kerja.

Jumlah pekerja dengan gangguan keluhan musculoskeletal di Great Britain berjumlah sebanyak $40 \%$ dari seluruh pekerja, dan mencapai $4 \%$ pada tahun 2001 hingga 2004 (Oley, R.A., South, L. F., \& Asrifuddin, 2018). U.S Beureau of Labour Statistics juga menyebutkan gangguan musculoskeletal yang diakbitkan oleh pekerjaan adalah pada bagian punggung. Pada tahun 2016, gangguan musculoskeletal pada punggung sebanyak $38,5 \%$ dari keseluruhan gangguan musculoskeletal terkait pekerjaan (134.550 kasus punggung dari 349.050 total kasus). Buruh dan memindahkan barang mengalami gangguan pada punggung sebanyak 10.660 kasus, asisten perawat mengalami gangguan punggung sebanyak 
10.330 kasus. Dibandingkan pekerjaan lain, pengemudi truk traktor yang berat memiliki proporsi cidera yang lebih besar yang mempengaruhi bahu $(19,2 \%)$ dan kaki $(16,3 \%)$ (U.S Bureau of Labour Statistis, 2018).Aktivitas kerja di CV. Amanah khususnya pekerjaan angkat angkut masih dilakukan secara manual dan mengandalkan tenaga manusia. $\mathrm{CV}$. Amanah memiliki pekerja sebanyak 31 orang yang bekerja sebagai tenaga angkatangkut.Berdasarkan observasi awal yang dilakukan di pengangkutan CV. Amanah ditemukan dari 10 orang pekerja yang ditemui, 5 orang diantaranya merasakan nyeri pada punggung dan 1 pekerja mengeluhkan rasa nyeri dari punggung bawah sampai ke kaki. Berdasarkan hal tersebut peneliti merasa perlu melakukan penelitian "Pengaruh Manual Handling Terhadap Keluhan Musculoskeletal Disorders pada Pekerja Angkat Angkut di CV. Amanah. Adapun tujuan dari penelitian ini adalah untuk mengetahui pengaruh manual handling terhadap keluhan musculoskeletal disorders pada pekerja angkat angkut di CV. Amanah.

\section{METODE}

Penelitian ini merupakan penelitian kuantitatif dengan metode studi analitik dengan pendekatan cross sectional. Penelitian dilakukan pada agustus 2021 dengan populasi 31 petugas angkat angkut CV. Amanah. Teknik pengambilan sampel dalam penelitian ini menggunakan total sampling. Variabel bebas dalam penelitian ini adalah aktivitas manual handling yang diukur menggunakan observasi dan penelitian berdasarkan lembar pengkuran OWAS (Ovako Work Posture Analysis System). Sedangkan variabel terikatnya adalah keluhan musculoskeletal disorders diukur menggunakan tabel Nordic Body Map (NBM). Data yang diperoleh kemudian diolah dengan metode pengolahan analisis univariat dan bivariat dengan uji statistik chi-square. Hasil analisis data disajikan dalam bentuk tabel dan dinarasikan secara deskriptif.

\section{HASIL}

Berdasarkan karakteristik subjek penelitian dapat diketahui bahwa seluruh responden berjenis kelamin laki-laki $(100 \%)$. Hasil penelitian dapat dilihat pada tabel-tabel berikut.

Tabel 1. Distribusi responden berdasarkan manual handling pada pekerja angkat angkut di $\mathrm{CV}$. Amanah

\begin{tabular}{lcc}
\hline \multicolumn{1}{c}{$\begin{array}{c}\text { Aktivitas } \\
\text { manual handling }\end{array}$} & \multicolumn{2}{c}{ Frekuensi } \\
\hline \multicolumn{1}{c}{$\mathbf{N}$} & $\mathbf{\%}$ \\
\hline Tidak beresiko & 17 & 54,8 \\
\hline Berisiko sedang & 3 & 9,7 \\
\hline Berisiko tinggi & 8 & 25,8 \\
\hline $\begin{array}{l}\text { Berisiko sangat } \\
\text { tinggi }\end{array}$ & 3 & 9,7 \\
\hline Jumlah & $\mathbf{3 1}$ & $\mathbf{1 0 0}$ \\
\hline
\end{tabular}

Dari hasil analisis univariat manual handling (tabel 1) dapat dilihat bahwa aktivitas manual handling paling banyak terdapat pada kategori tidak berisiko sebanyak 17 responden $(54,8 \%)$.

Tabel 2. Distribusi responden berdasarkan keluhan musculoskeletal disorders pada pekerja angkat angkut di CV. Amanah

\begin{tabular}{lcc}
\hline $\begin{array}{l}\text { Keluhan } \\
\text { musculoskeletal } \\
\text { disorders }\end{array}$ & \multicolumn{2}{c}{ Frekuensi } \\
\hline & n & \% \\
\hline Rendah & 18 & 58,1 \\
\hline Sedang & 7 & 22,6 \\
\hline Tinggi & 6 & 19,4 \\
\hline Jumlah & $\mathbf{3 1}$ & $\mathbf{1 0 0}$ \\
\hline
\end{tabular}

Dari hasil analisi univariat keluhan musculoskeletal disorders (tabel 2) dapat dilihat bahwa keluhan musculoskeletal disorders paling banyak terdapat pada kategori tingkat keluhan rendah yaitu sebanyak 18 responden $(58,1 \%)$. 
Tabel 3. Uji Pengeruh Manual Handling Terhadap Keluhan Musculoskeletal Disorders Pada Pekerja Angkat Angkut Di CV. Amanah

\begin{tabular}{|c|c|c|c|c|c|c|c|c|c|}
\hline \multirow{3}{*}{$\begin{array}{c}\text { Aktivitas } \\
\text { manual } \\
\text { handling }\end{array}$} & \multicolumn{6}{|c|}{ Keluhan musculoskeletal disorders } & \multicolumn{2}{|c|}{ Jumlah } & \multirow[t]{3}{*}{$\rho$ value } \\
\hline & \multicolumn{2}{|c|}{ rendah } & \multicolumn{2}{|c|}{ sedang } & \multicolumn{2}{|c|}{ Tinggi } & & & \\
\hline & $\mathbf{N}$ & $\%$ & $\mathbf{N}$ & $\%$ & $\mathbf{N}$ & $\%$ & $\mathbf{N}$ & $\%$ & \\
\hline $\begin{array}{l}\text { Tidak } \\
\text { berisiko }\end{array}$ & 15 & 88,2 & 2 & 11,8 & 0 & 0,0 & 17 & 100 & 0,000 \\
\hline $\begin{array}{l}\text { Berisiko } \\
\text { sedang }\end{array}$ & 2 & 66,7 & 1 & 333,3 & 0 & 0,0 & 3 & 100 & \\
\hline $\begin{array}{l}\text { Berisiko } \\
\text { tinggi }\end{array}$ & 1 & 12,5 & 4 & 50,0 & 3 & 37,5 & 8 & 100 & \\
\hline $\begin{array}{l}\text { Berisiko } \\
\text { sangat tinggi }\end{array}$ & 0 & 0,0 & 0 & 0,0 & 3 & 100 & 3 & 100 & \\
\hline Jumlah & 18 & 58,1 & 7 & 22,6 & 6 & 19, 4 & 31 & 100 & \\
\hline
\end{tabular}

Berdasarkan hasil penelitian yang telah dilakukan, adapun hasil analisis pengaruh manual handling terhadap keluhan musculoskeletal disorders pada pekerja angkat angkut di CV. Amanah ditunjukkan pada Tabel 3. Berdasarkan hasil analisis uji Chi-square, nilai $\rho$ value yang didapat adalah 0,000 . Dimana nilai $\rho$ value lebih kecil dari $\alpha(\alpha=0,05)$ yang memiliki arti bahwa ada pengaruh aktivitas manual handling terhadap keluhan musculoskletal disorders pada pekerja angkat angkut di CV. Amanah.

\section{PEMBAHASAN}

Hasil penelitian menunjukkan bahwa terdapat pengaruh manual handling terhadap keluhan musculoskeletal disorders pada pekerja angkat angkut di CV. Amanah dengan nilai $\rho$ value 0,000 . Hal ini terjadi karena semakin baik sikap kerja pekerja saat melakukan aktivitas manual handling maka semakin rendah pula keluhan musculoskeletal disorders yang dialami oleh pekerja.

Penelitian ini sejalan dengan penelitian yang telah dilakukan oleh Noe (2020) dimana diperoleh rata-rata seluruh pekerja memiliki risiko aktivitas manual handling dikarenakan kegiatan angkat-angkut yang masih dilakukan secara manual tanpa dibantu alat apapun dan postur kerja janggal yang sering dilakukan. Beberapa peneliti lain juga menunjukan bahwa terdapat hubungan antara aktivitas manual handling dengan risiko penyakit musculoskeletal disorders pada pekerja buruh angkut (Noe, 2020).

Akibat yang ditimbulkan dari aktivitas manual handling yang tidak baik dapat menyebabkan rasa sakit pada bagian otot skeletal yang dirasakan oleh pekerja, yang dimulai dari keluhan rendah sampai keluhan yang tinggi. Apabila otot terus menerus menerima beban statis dan secara berulang dalam jangka waktu yang cukup lama dapat menyebabkan kerusakan pada sendi, ligamen, dan tendon. Hal ini sejalan dengan penelitian yang dilakukan oleh Kharisma (2021) yang menyatakan bahwa terdapat hubungan yang sangat signifikan antara risiko pekerjaan manual handling dengan keluhan musculoskeletal (Kharisma, 2021).

Bagian pada sikap kerja yang diamati meliputi pergerakan tubuh dari bagian punggung, bahu, tangan, dan kaki (termasuk paha, lutut, pergelangan kaki). Hasil pengukuran menunjukkan hasil dengan empat kategori yang dialami oleh pekerja yaitu kategori tidak berisiko, berisiko sedang, berisiko tinggi, dan berisiko sangat tinggi. Pekerja yang tidak memiliki risiko sebanyak 17 responden, hal ini disebabkan karena sikap kerja dan beban kerja yang diangkat masih dalam kategori cukup baik dan tidak diperlukan tindakan perbaikan.

Pekerja yang memiliki risiko sedang sebanyak 3 resonden, pada sikap ini dapat menyebabkan kerusakan pada sistem musculoskeletal (postur kerja mengakibatkan pengaruh ketegangan yang 
signifikan dan berisiko rendah) dan perlu dilakukan perbaikan dikemudian hari. Selanjutnya pekerja yang memiliki risiko tinggi sebanyak 8 resonden, pada sikap ini berbahaya pada sistem musculoskeletal (postur kerja mengakibatkan pengaruh ketegangan yang signifikan dan berisiko tinggi) dan perlu perbaikan sesegera mungkin. Kemudian pekerja yang memiliki risiko sangat tinggi sebanyak 3 resonden, pada sikap ini sangat berbahaya pada sistem musculoskeletal (postur kerja ini mengakibatkan risiko yang jelas atau risiko yang sangat tinggi) dan perlu perbaikan secara langsung dan segera.

Berdasarkan hasil penelitian keluhan musculoskeletal disorders pada pekerja responden, didapatkan hasil 18 responden memiliki keluhan dengan kategori rendah, 7 responden memiliki keluhan dengan kategori sedang dan 6 responden memiliki keluhan dengan kategori tinggi. Dari hasil yang didapatkan sebagian pekerja memiliki keluhan musculoskeoetal disorders, hal ini dikarenakan faktor pekerja angkat angkut di CV. Amanah masih bekerja secara manual handling tanpa menggunakan alat bantu apapun dan juga adanya aktivitas janggal yang sering dilakukan.

Selain itu, faktor penyebab keluhan muskuloskeletal pada pekerja angkat angkut mengeluhkan rasa sakit bagian bahu kiri, bahu kanan, pinggang, punggung, lutut, paha. Keluhan tersebut disebabkan karena aktivitas pekerjaan angkat angkut yang dilakukan setiap hari. Sebagian responden mengalami keluhan sakit di bahu karena pada bagian ini mengalami posisi statis yang cukup lama saat mengangkut barang sampai ke tempat yang dituju serta terkadang pekerja membawa beban dengan berat yang tidak seimbang.

Pada saat mengangkat barang posisi pinggang dan punggung sedikit membungkuk karena beban yang diangkat melebihan kapasitas. Hal tersebut diakibatkan oleh tubuh yang dipengaruhi pengaturan daerah kerja yang tidak ergonomis sehingga posisi-posisi tubuh pekerja dalam beraktivitas merasa dibatasi, sehingga menimbulkan masalah-masalah pada tubuh seperti tubuh pekerja terlalu membungkuk mengakibatkan nyeri pada punggung (Kharisma, 2021).

Pada bagian lutut, dan paha, untuk menopang beban dengan berat yang melebihi kapasitas dalam waktu yang cukup lama sehingga menimbulkan kelelahan dan rasa sakit. Bekerja dalam posisi berjalan dengan mengangkut barang untuk jangka waktu panjang secara terus menerus dapat menyebabkan kaki sakit, kelelahan otot, nyeri pinggang serta timbul kekakuan pada leher dan bahu (Tamene, A., Mulugeta, H., Ashenafi, 2020)

Postur kerja yang dipaksakan dalam melakukan kegiatan manual handling atau angkat-angkut secara terus-menerus akan menimbulkan keluhan sistem muskuloskeletal, terlebih kegiatan di CV. Amanah tidak memiliki aturan mengenai berat beban yang akan diangkut dan juga posisi tubuh yang sesuai untuk kegiatan angkat-angkut.

\section{KESIMPULAN}

Berdasarkan hasil penelitian, dapat disimpulkan bahwa ada pengaruh manual handling terhadap keluhan muscuoskeletal disorders pada pekerja angkat angkut di CV. Amanah. Semakin baik postur kerja pekerja saat melakukan aktivitas manual handling maka risiko keluhan musculoskeletal disorders akan semakin rendah pula.

\section{UCAPAN TERIMAKASIH}

Peneliti mengucapkan terimakasih kepada semua pihak yang telah berkontribusi dalam penelitian ini, terutama kepada Komisaris CV. Amanah yang telah memberikan izin kepada peneliti untuk melakukan penelitian di CV. Amanah, kepada responden yang telah bersedia membantu peneliti, serta seluruh pihak yang tidak dapat disebutkan satu persatu. 


\section{DAFTAR PUSTAKA}

Azis, A. (2018). Faktor Yang Berhubungan Dengan Keluhan Nyeri Otot Skeletal (Musculoskeletal Disorders) Pada Pekerja Bongkar Muat di Pelabuhan Soekarno Hatta Makassar. Skripsi Program Studi Kesehatan Masyarakat.

Cho K, Cho HY, H. G. (2016). Risk Factors Associated With Musculoskeletal Symptoms in Korean Dental Practitioners. J Phys Ther Sci, 28(1).

HSE. (2019). Work telated muscoluskeletal disorders in Great Britania (WRMSDs). Heal Saf. Exec, 1(2).

ILO. (2018). Menuju Budaya Pencegahan Keselamatan dan Kesehatan Kerja yang Lebih Kuat di Indonesia.

Kemenkes. (2014). Infodatin-Kesehatan dan Keselamatan Kerja.

Kharisma, S. A. (2021). Hubungan Risiko Pekerjaan Manual Handling Dengan Keluhan Muskuloskeletal Pada Pekerja Kuli Panggul Wanita di Pasar Legi Surakarta. Skripsi Program Studi Kesehatan Masyarakat.

Noe, A. R. (2020). Hubungan Antara
Aktivitas Manual Handling, Postur kerja, dan Faktor Individu dengan Risiko Penyakit Musculoskeletal Disorders pada Pekerja Angkat Angkut di UD. Barokah. Skripsi Program Studi Kesehatan Masyarakat.

Oley, R.A., South, L. F., \& Asrifuddin, A. (2018). Hubungan Antara Sikap Kerja dan Masa Kerja Dengan Keluhan Musculoskeletal Pada Nelayan di Kelurahan Bantukota Kecamatan Lembeh Utara Kota Bitung Tahun 2018. Kesmas.

Tamene, A., Mulugeta, H., Ashenafi, T. (2020). Musculoskeletal Disorders and Associated Factors Among Vaehicle Repair Workers in Hawassa City, Southern Ethiopia. Journal Environ Public Health. https://doi.org/https://doi.org/10.115 5/2020/9472357

Tarwaka. (2018). Erogonomi Industri: Dasar-Dasar Pengetahuan Ergonomi dan Aplikasi di Tempat Kerja. Harapan Press.

U.S Bureau of Labour Statistis. (2018). Back Injureies Prominent in WorkRelated Musculoskeletal Disorders Cases in 2016. 